\title{
PENENTUAN USAHA PERIKANAN TANGKAP UNGGULAN DAN KESIAPAN FASILITAS PENDUKUNG DI KAWASAN PPS KENDARI, SULAWESI TENGGARA
}

\section{Determination of Superior Capture Fishing and Readiness of Supporting Facilities in PPS Kendari Area, South-East Sulawesi}

Oleh:

\author{
Mustaruddin $^{1}$, Riena F. Telussa ${ }^{2}$, Mulyono S. Baskoro ${ }^{1}$ \\ ${ }^{1}$ Departemen Pemanfaatan Sumberdaya Perikanan, FPIK, IPB University \\ ${ }^{2}$ Jurusan Pemanfaatan Sumberdaya Perikanan, FPIK, USNI \\ Korespondensi:mus_m03@yahoo.com
}

\begin{abstract}
ABSTRAK
PPS Kendari harus kuat dari sisi penyediaan bahan baku ikan hasil tangkapan karena menjadi sentra collecting ikan sekaligus sebagai pusat pertumbuhan dan pengembangan ekonomi terpadu berbasis perikanan. Pengembangan usaha perikanan tangkap terunggulkan yang ditopang oleh kesiapan fasilitas pendukung yang baik diyakini dapat membantu penyediaan ikan hasil tangkapan secara optimal. Penelitian ini bertujuan menentukan jenis usaha perikanan tangkap unggulan dan tingkat kesiapan fasilitas pendukung di kawasan PPS Kendari. Metode yang digunakan terdiri dari metode skoring dan analisis tingkat kesiapan (readiness level). Hasil penelitian menunjukkan bahwa purse seine, jaring insang hanyut, payang, dan pancing tonda terpilih sebagai usaha perikanan tangkap unggulan untuk dikembangkan di kawasan PPS Kendari. Fasilitas pendukung dengan kesiapan tinggi adalah pelabuhan perikanaan, SPBU, kios perbekalan, instalasi air bersih, pabrik es, cold storage, dan sarana lainnya (LPPMHP dan perbankan). Fasilitas pendukung dengan kesiapan sedang adalah fasilitas docking, TPI/pasar ikan, dan instalasi listrik.
\end{abstract}

Kata kunci: perikanan tangkap, PPS Kendari, sentra collecting, tingkat kesiapan

\section{ABSTRACT}

PPS Kendari must be strong in terms of the supply of captured fish, because it is a center for collecting ikan and also as a center for growth and development of an integrated economy based on fisheries. The development of superior capture fishing, which supported by the readiness of good supporting facilities, are believed to be able to help supply fish optimally. This study aims to determine the type of superior capture fishing and the readiness level of supporting facilities in the PPS Kendari area. Methods used consists of scoring method and readiness level analysis. Results showed that purse seine, drift gillnet, payang, and trolling were selected as superior capture fishing to be developed in Kendari PPS area. Supporting facilities with high readiness were fishing ports, oil stations, supply store, clean water installations, ice factories, cold storage, and other facilities (LPPMHP and banking). Supporting facilities with moderate readiness were docking facilities, fish auction places/fish market, and electric installations.

Key words: capture fisheries, collecting centers, Kendari PPS, readiness level 


\section{PENDAHULUAN}

Provinsi Sulawesi Tenggara merupakan salah satu sentra perikanan tangkap di wilayah Indonesia Timur. Hal ini karena posisinya yang strategis berbatasan langsung dengan dua "Wilayah Pengelolaan Perikanan" (WPP) RI, yaitu WPP-RI 713 dan WPP-RI 714. Dalam "Sistem Logistik Ikan Nasional” (SLIN), Provinsi Sulawesi Tenggara masuk dalam koridor I logistik ikan, dimana Kendari, dalam hal ini Pelabuhan Perikanan Samudera (PPS) Kendari menjadi sentra collecting ikan. Posisi ini menjadikan PPS Kendari sebagai tujuan pendaratan utama berbagai usaha perikanan tangkap yang beroperasi di WPP-RI 714 dan WPP-RI 713 areal Sulawesi. Untuk mendukung pengembangan PPS Kendari, pada tahun 2015 Kementerian Kelautan dan Perikanan menjadikan PPS Kendari sebagai pusat pertumbuhan dan pengembangan ekonomi perikanan terpadu di wilayah Indonesia Timur (KKP 2014). Hal ini memperluas peran PPS Kendari yang tidak hanya sentra collecting, tetapi juga sentral bagi kegiatan industri perikanan, baik industri hulu maupun hilir; pertumbuhan dan pengembangan ekonomi perikanan terpadu yang menjalankan aktivitas produksi ikan, penanganan dan pengolahan ikan, pengawasan mutu produk perikanan, pemasaran hasil perikanan, serta pembinaan masyarakat nelayan.

Untuk mendukung peran sebagai sentra collecting dalam SLIN sekaligus sebagai pusat pertumbuhan dan pengembangan ekonomi terpadu berbasis perikanan, maka PPS Kendari harus kuat dari sisi penyediaan bahan baku ikan hasil tangkapan. Dalam konteks ini, maka pengembangan operasi penangkapan ikan terutama dengan mengandalkan usaha perikanan tangkap terunggulkan mutlak diperlukan. Usaha perikanan tangkap unggulan nantinya menjadi pemasok utama ikan segar yang dibutuhkan dalam collecting ikan di koridor I logistik ikan maupun yang digunakan langsung oleh industri perikanan, usaha pengolahan, usaha pemasaran, dan kegiatan ekonomi perikanan lainnya di PPS Kendari. Usaha perikanan tangkap unggulan tersebut perlu dikaji karena secara signifikan dapat mengotimalkan keberhasilan operasi penangkapan ikan di kedua WPP, seperti di wilayah Kepulauan Muna, Kepulauan Wakatobi, Kepulauan Buton dan Konawe, serta di wilayah selatan yang mencakup Laut Banda dan Laut Flores (Ditjen Perikanan Tangkap 2018, Anggoro et al 2019).

Operasi penangkapan ikan dengan mengandalkan usaha perikanan tangkap terunggulkan tidak akan berhasil maksimal bila fasilitas pendukung, baik yang menopang operasi penangkapan ikan maupun kegiatan pasca operasi penangkapan ikan tidak siap. Sebagai pelabuhan perikanan tipe A, PPS Kendari seharusnya mempunyai fasilitas pendukung yang lengkap. Namun seberapa jauh tingkat kesiapan fasilitas pendukung tersebut menjadi kunci utama keberhasilan PPS Kendari sebagai sentra collecting ikan sekaligus sebagai pusat pertumbuhan dan pengembangan ekonomi berbasis perikanan. Penelitian ini diharapkan dapat membantu pemecahannya. Tujuan penelitian adalah menentukan jenis usaha perikanan tangkap unggulan dan menganalisis tingkat kesiapan fasilitas pendukung di kawasan PPS Kendari.

\section{METODE PENELITIAN}

Penelitian ini dilakukan di kawasan Pelabuhan Perikanan Samudera (PPS) Kendari, Kota Kendari, Sulawesi Tenggara. Waktu pelaksanaan penelitian bulan Oktober 2016-Januari 2017. Data yang dikumpulkan dalam penelitian ini terdiri dari : (a) data usaha perikanan tangkap mencakup data teknis dan sosio-lingkungan dari pengoperasian usaha perikanan tangkap, (b) data fasilitas pendukung di kawasan PPS Kendari, mencakup pelabuhan, fasilitas docking, SPBU, kios perbekalan, instalasi air bersih, pabrik es, cold storage, TPI/pasar ikan, instalasi listrik, dan sarana lainnya. Data teknis dan sosiolingkungan usaha perikanan tangkap dikumpulkan melalui penyebaran kuesioner. Sedangkan data fasilitas pendukung dikumpulkan melalui pengamatan langsung dan studi pustaka. 
Untuk penyebaran kuesioner, responden yang dituju adalah nakhoda/nelayan pemilik sekitar 45 orang, dimana setiap usaha perikanan tangkap masing-masing 5 orang. Sedangkan usaha perikanan tangkap yang dipilih sebagai opsi unggulan adalah yang banyak dikembangkan dan aktif dioperasikan di PPS Kendari. Usaha perikanan tangkap tersebut adalah rawai dasar, payang, bagan perahu, purse seine, jaring insang hanyut, jaring lingkar, pancing tonda, jaring insang tetap, dan pole and line (PPS Kendari, 2016). Pemilihan nakhoda/nelayan pemilik yang menjadi responden dilakukan secara incidental sampling di kawasan PPS Kendari. Studi pustaka dilakukan dengan menelaah buku laporan dan hasil studi terkait usaha perikanan tangkap dan fasilitas pendukung perikanan yang tersedia di PPS Kendari, Dinas Kelautan dan Perikanan Provinsi Sulawesi Tenggara, Direktorat Jenderal Perikanan Tangkap, perguruan tinggi, dan lembaga penelitian.

Analisis data dalam penelitian ini menggunakan metode skoring dan analisis tingkat kesiapan (readiness level). Analisis skoring digunakan untuk menentukan jenis usaha perikanan tangkap unggulan untuk dikembangkan di kawasan PPS Kendari. Untuk meningkatkan akurasi analisis, maka skoring dilakukan secara jamak terhadap dua aspek utama pengelolaan usaha perikanan tangkap, yaitu aspek teknis dan aspek sosio-lingkungan. Menurut Mustaruddin et al (2017) dan FAO (1995), aspek teknis berkaitan dengan operasionalisasi usaha perikanan tangkap, sedangkan aspek sosio-lingkungan berkaitan dengan sesuatu yang timbul setelah operasi penangkapan terhadap kehidupan masyarakat dan lingkungan sekitar. Dalam penelitian ini, penilaian aspek teknis menggunakan kriteria kelengkapan peralatan produksi, kapasitas palka, kapasitas muat es, penyerapan tenaga kerja/ABK, kapasitas mesin penggerak, dan ukuran armada. Sedangkan penilaian aspek sosio-lingkungan menggunakan kriteria penerapan teknologi tepat guna, jumlah hasil tangkapan, tingkat investasi, selektivitas alat tangkap, keramahan terhadap habitat ikan, dan keamanan produk bagi konsumen. Hasil penilaian kriteria kemudian distandarkan menggunakan persamaan (Kuntoro dan Listiarini, 1983):

$$
\begin{aligned}
& V(X)=\frac{X i-X 0}{X 1-X 0} \\
& V(A)=\sum V i(X i)
\end{aligned}
$$

Pada persamaan tersebut, $\mathrm{Xi}=$ nilai kriteria $\mathrm{X}$ dari usaha perikanan tangkap ke-i, $\mathrm{X} 0=$ nilai terendah untuk kriteria $X, X 1=$ nilai tertinggi untuk kriteria $X, V(X)=$ fungsi nilai dari kriteria $X, V(A)$ = akumulasi fungsi nilai dari semua kriteria untuk suatu usaha perikanan tangkap, dan $\mathrm{i}=1,2,3, \ldots . .9$ (opsi usaha perikanan tangkap unggulan). Sebanyak 4 dari 9 opsi usaha perikanan tangkap selanjutnya dipilih sebagai unggulan.

Analisis tingkat kesiapan/readiness level (RL) digunakan untuk menganalisis kesiapan fasilitas pendukung di kawasan PPS Kendari. Analisis RL ini menggunakan dua kriteria teknis (kelengkapan fisik fasilitas dan kapasitas fasilitas terpasang) dan tiga kriteria sosio-lingkungan (kedekatan fasilitas, keaktifan operasi fasilitas, dan pengelolaan dampak operasi fasilitas). Analisis tingkat kesiapan kesiapan/readiness level(RL) menggunakan persamaan:

$$
R L=\frac{\sum_{1}^{n} r_{i}}{n}
$$

Pada persamaan tersebut, $r_{i}=$ nilai kriteria ke-i, $\mathrm{RL}=$ readiness level/tingkat kesiapan, dan $\mathrm{i}=$ $1,2,3, \ldots ., 5$ (kriteria kesiapan fasilitas). Kategori tingkat kesiapan yang digunakan adalah (a) kesiapan tinggi bila RL : >2-3, (b) kesiapan sedang bila RL : >1-2, dan (c) tidak siap bila RL = 0-1. 


\section{HASIL DAN PEMBAHASAN}

\section{Usaha Perikanan Tangkap Unggulan}

Penentuan usaha perikanan tangkap unggulan perlu dilakukan secara jamak dengan menilai performa beberapa opsi usaha perikanan tangkap baik dari aspek teknis maupun sosio-lingkungan. Hal ini penting supaya usaha perikanan tangkap yang terpilih benar-benar handal dan terbaik untuk kompleksitas kondisi perikanan tangkap di Kendari. Tabel 1 dan Tabel 2, menyajikan hasil penilaian aspek teknis dan sosio-lingkungan dari usaha perikanan tangkap yang ada di kawasan PPS Kendari.

Tabel 1 Hasil penilaian aspek teknis

\begin{tabular}{clcccccc}
\hline No. & Usaha Perikanan Tangkap & X1 & X2 & X3 & X4 & X5 & X6 \\
\hline 1 & Rawai Dasar & 2 & 1500 & 12 & 9 & 15 & 8 \\
2 & Payang & 3 & 5000 & 24 & 11 & 30 & 20 \\
3 & Bagan Perahu & 4 & 6000 & 28 & 12 & 20 & 25 \\
4 & Purse Seine & 4 & 7500 & 40 & 16 & 45 & 28 \\
5 & Jaring Insang Hanyut & 4 & 17500 & 70 & 15 & 40 & 75 \\
6 & Jaring Lingkar & 3 & 10500 & 50 & 12 & 25 & 30 \\
7 & Pancing Tonda & 2 & 5000 & 22 & 8 & 25 & 15 \\
8 & Jaring Insang Tetap & 2 & 8000 & 30 & 9 & 35 & 20 \\
9 & Pole and Line & 3 & 15000 & 55 & 13 & 40 & 35 \\
\hline
\end{tabular}

Keterangan: $\mathrm{X} 1$ = kelengkapan peralatan produksi; X2 = kapasitas palka (kg/trip); X3 = kapasitas muat es (balok/trip); X4 = penyerapan tenaga kerja/ABK (orang/unit); X5 = kapasitas mesin penggerak (PK); X6 = ukuran armada (GT).

Berdasarkan Tabel 1, untuk kriteria kelengkapan peralatan produksi, bagan perahu, purse siene, dan jaring insang hanyut termasuk paling baik. Sedangkan untuk kapasitas palka, jaring insang hanyut dan pole and line adalah yang paling besar, yaitu masing-masing sekitar 17.500 ton dan 15.000 ton. Sedangkan untuk kapasitas muat es balok, jaring insang hanyut, pole and line, jaring lingkar, dan purse seine termasuk yang besar. Hal ini selain karena skala pengusahaan yang besar, juga jumlah hari operasi per trip yang rata-rata lebih lama. Untuk purse seine dan pole and line misalnya bisa 1-3 minggu, dan beberapa ada yang sampai bulanan (Mustaruddin et al 2017, Anggoro et al 2015). Untuk penyerapan tenaga kerja, hanya rawai dasar, pancing tonda, dan jaring insang tetap yang relatif sedikit. Penyerapan tenaga kerja terbanyak ada pada jaring insang hanyut. Penyerapan tenaga kerja pada payang cukup variatif tergantung ukuran kapal yang digunakan, dimana bila ukurannya besar bisa mencapai 15-20 orang.

Untuk kriteria kapasitas mesin penggerak dan ukuran kapal, jaring insang hanyut, dan pole and line umumnya menggunakan mesin penggerak kapasitas besar dan ukuran kapal yang juga besar. Jaring insang hanyut umumnya menggunakan kapal 75 GT dan pole and line menggunakan kapal 35 GT. Menurut Samida et al (2018), kapal jaring insang dan pole and line yang berbasis di Kendari bisa beroperasi hingga fishing groud terjauh di WPP-RI 713 dan WPP-RI 714.

Untuk aspek sosio-lingkungan, rawai dasar, bagan perahu, payang, dan pancing tonda dinilai sebagai usaha perikanan tangkap yang paling banyak dikembangkan secara tepat guna. Untuk pancing tonda misalnya, nelayan mendesain sistem tali-temali dan kailnya sesuai dengan kebiasaan yang berkembang secara lokal (Hendri et al 2019). Untuk bagan perahu, kerangka bagan dan rumah bagan dibuat dari kayu dengan teknik desain yang diwariskan turun temurun. Kayu bagan di Sulawesi umumnya dipilih dari jenis kayu yang kuat yang ada di hutan bakau. Untuk hasil tangkapan, jaring insang hanyut, pole and line, dan purse seine termasuk yang paling banyak, yaitu masing-masing 12.012 $\mathrm{kg} /$ trip, $9.285 \mathrm{~kg} /$ trip, dan $6.520 \mathrm{~kg} /$ trip. Untuk kriteria tingkat investasi, payang, purse seine, dan jaring insang tetap (JIT) termasuk yang paling tinggi di Kendari. Hal ini bisa dilihat dari populasi ketiga alat 
tangkap tersebut pada tahun 2015 yang relatif tinggi, yaitu masing-masing 100 unit, 287 unit, dan 100 unit.

Tabel 2 Hasil penilaian aspek sosio-lingkungan

\begin{tabular}{clcccccc}
\hline No. & Usaha Perikanan Tangkap & X1 & X2 & X3 & X4 & X5 & X6 \\
\hline 1 & Rawai Dasar & 4 & 752 & 2 & 3 & 4 & 2 \\
2 & Payang & 3 & 4528 & 4 & 2 & 1 & 4 \\
3 & Bagan Perahu & 4 & 5206 & 2 & 2 & 2 & 1 \\
4 & Purse Seine & 1 & 6520 & 4 & 1 & 3 & 2 \\
5 & Jaring Insang Hanyut & 1 & 12012 & 3 & 2 & 3 & 2 \\
6 & Jaring Lingkar & 2 & 4294 & 3 & 2 & 2 & 2 \\
7 & Pancing Tonda & 3 & 2550 & 3 & 3 & 4 & 4 \\
8 & Jaring Insang Tetap & 2 & 5948 & 4 & 2 & 2 & 2 \\
9 & Pole and Line & 2 & 9285 & 2 & 3 & 2 & 4 \\
\hline
\end{tabular}

Keterangan: X1 = penerapan teknologi tepat guna; X2 = jumlah hasil tangkapan (kg/trip); X3 = tingkat investasi; X4 = selektivitas alat tangkap; X5 = keramahan terhadap habitat ikan; dan X6 = keamanan produk bagi konsumen

Rawai dasar, pancing tonda, dan pole and line mempunyai selektivitas paling baik dibandingkan enam usaha perikanan tangkap lainnya. Hal ini karena ketiganya dioperasikan dengan sistem kail/pancing menggunakan jenis umpan tertentu, sehingga hanya ikan sasaran yang bisa tertangkap (Hendri et al 2019, Mustaruddin et al 2017). Untuk keramahan terhadap habitat, rawai dasar dan pancing tonda termasuk yang paling ramah karena interaksi dengan perairan dan sumberdaya ikan bersifat minimal. Meskipun pole and line interaksinya juga minimal dengan menerapkan sistem kail, tetapi karena mata kail bisa mengenai bagian mana saja dari tubuh ikan (tidak hanya di mulut), maka dianggap kurang ramah. Untuk kriteria keamanan produk bagi bagi konsumen, payang dan pancing tonda termasuk yang paling bagus. Ikan hasil tangkapan pole and line juga mempunyai keamanan yang tinggi bagi konsumen dominan karena tidak menggunakan umpan/bahan tertentu dalam penangkapannya, meskipun sistem operasinya sangat aktif. Menurut Huang et al (2016) dan Fernández et al (2013), umpan atau bahan tertentu yang digunakan dalam operasi penangkapan ikan, dapat menjadi kontaminan penting pada produk sehingga membahayakan konsumen.

Setelah hasil penilaian kedua aspek tersebut distandarisasi dan diperbandingkan, maka dilakukan penilaian gabungan. Hasil penilaian gabungan ini menjadi dasar dalam pemilihan usaha perikanan tangkap yang dapat diunggulkan untuk mendukung PPS Kendari sebagai sentra collecting ikan serta pusat pertumbuhan dan pengembangan ekonomi terpadu berbasis perikanan. Di samping itu, usaha perikanan tangkap tersebut diharapkan dapat menjamin kelangsungan pemanfaatan potensi sumberdaya ikan yang ada di WPP-RI 714 dan WPP-713. Tabel 3. menyajikan hasil standarisasi penilaian gabungan aspek teknis dan aspek sosio-lingkungan.

Berdasarkan Tabel 3, purse seine, jaring insang hanyut, payang, dan pancing tonda terpilih sebagai usaha perikanan tangkap unggulan untuk dikembangkan di kawasan PPS Kendari. Purse seine mempunyai nilai VA paling tinggi, yaitu 1,722, sehingga mendapatkan prioritas I (satu) untuk dikembangkan. Namun demikian, ke empat usaha perikanan tangkap dapat menjadi pilihan utama untuk mendukung PPS Kendari sebagai sentra collecting ikan serta pusat pertumbuhan dan pengembangan ekonomi terpadu berbasis perikanan. Nilai VA jaring insang hanyut, payang, dan pancing tonda masing-masing 1,713, 1,607, dan 1,302. Menurut Mustaruddin et al (2015), usaha perikanan tangkap yang dinyatakan unggul berdasarkan pertimbangan berbagai aspek pengelolaan, diyakini lebih sukses dalam investasi produksi/penyediaan bahan baku ikan hasil tangkapan. Hal ini karena usaha perikanan tangkap tersebut lebih dapat mengakomodir berbagai kepentingan dan perubahan yang terjadi dalam kegiatan bisnis perikanan tangkap. Prabowo et al (2013) dan Septia et al (2012) menyatakan bahwa tersedianya informasi usaha perikanan tangkap unggulan mendorong 
investasi perikanan tangkap baik yang bersumber PMDN maupun PMA. Bila hal ini terjadi, maka dapat membuka lapangan kerja baru, meningkatkan PAD, dan mendorong pertumbuhan ekonomi daerah.

Tabel 3. Hasil standarisasi penilaian gabungan

\begin{tabular}{clcccr}
\hline No. & Usaha Perikanan Tangkap & V1 & V2 & VA & UP \\
\hline 1 & Rawai Dasar & 0,000 & 0,339 & 0,339 & 9 \\
2 & Payang & 0,332 & 1,275 & 1,607 & 3 \\
3 & Bagan Perahu & 0,421 & 0,000 & 0,421 & 8 \\
4 & Purse Seine & 0,722 & 1,000 & 1,722 & 1 \\
5 & Jaring Insang Hanyut & 1,000 & 0,713 & 1,713 & 2 \\
6 & Jaring Lingkar & 0,493 & 0,328 & 0,822 & 7 \\
7 & Pancing Tonda & 0,126 & 1,176 & 1,302 & 4 \\
8 & Jaring Insang Tetap & 0,280 & 0,972 & 1,251 & 5 \\
9 & Pole and Line & 0,684 & 0,390 & 1,074 & 6 \\
\hline
\end{tabular}

Keterangan: $\mathrm{Vi}$ = fungsi nilai aspek teknis; $\mathrm{V} 2=$ fungsi nilai aspek sosio-lingkungan; $\mathrm{VA}=$ fungsi nilai gabungan

\section{Fasilitas Pendukung Perikanan Tangkap}

Fasilitas pendukung merupakan penopang penting pengembangan usaha perikanan tangkap unggulan, karena mendukung berbagai kebutuhan melaut, pendaratan ikan hasil tangkapan, pemasaran ikan, dan jasa layanan yang dibutuhkan pelaku usaha perikanan tangkap. Secara umum, fasilitas pendukung perikanan tangkap di kawasan PPS Kendari secara terbagi dua, yaitu fasilitas pendukung operasi penangkapan ikan dan fasilitas pendukung pasca operasi penangkapan ikan. Tabel 4 menyajikan ragam fasilitas pendukung perikanan tangkap yang tersedia di kawasan PPS Kendari.

Tabel 4. Fasilitas pendukung usaha perikanan tangkap

\begin{tabular}{|c|c|c|c|}
\hline No. & Fasilitas Pendukung & Kuantitas & Keterangan \\
\hline 1 & Pelabuhan Perikanan & 1 set & $\begin{array}{l}\text { Dermaga, kolam, system nagivasi, wilayah operasi } \\
\text { daratan } 59,34 \mathrm{Ha} \text {, dan perairan } 8,72 \mathrm{Ha}\end{array}$ \\
\hline 2 & Fasilitas Docking & 1 set & $\begin{array}{l}\text { Tempat perbaikan kapal dan tempat perbaikan alat } \\
\text { tangkap }\end{array}$ \\
\hline 3 & SPBU & 2 unit & $\begin{array}{l}\text { Mendukung operasi unit penangkapan ikan skala } \\
\text { besar dan skala kecil }\end{array}$ \\
\hline 4 & Kios Perbekalan & 25-30 unit & $\begin{array}{l}\text { Kios kebutuhan melaut, kios peralatan, kios } \\
\text { kebutuhan pendukung lainnya }\end{array}$ \\
\hline 5 & Instalasi Air Bersih & 2 sumber & PDAM dan air tanah. Ada WWT dan buffer tank \\
\hline 6 & Pabrik Es & 12 unit & Pabrik es, mesin penghancur es, \\
\hline 7 & Cold Storage & 24 unit & Kapasitas 150 ton, 100 ton, dan 50 ton \\
\hline 8 & TPI/pasar ikan & 1 unit & Cukup luas befungsi baik, tiang beton baja \\
\hline 9 & Instalasi Listrik & 2 sumber & PLN dan Genset Pelabuhan \\
\hline 10 & Sarana lainnya & 4 Set & $\begin{array}{l}\text { LPPMHP, layanan perbankan, komunikasi, } \\
\text { sarana pembinaan nelayan }\end{array}$ \\
\hline
\end{tabular}

Berdasarkan Tabel 4, fasilitas pendukung operasi maupun pasca operasi penangkapan ikan cukup lengkap. Fasilitas pendukung operasi penangkapan yang tersedia terdiri dari pelabuhan perikanan, SPBU, kios perbekalan, instalasi air bersih, dan pabrik es. Sedangkan fasilitas pendukung pasca operasi penangkapan ikan, terdiri dari cold storage, fasilitas docking, TPI/pasar ikan, fasilitas listrik, dan sarana lainnya. Sarana lainnya terdiri dari laboratorium pengujian mutu (LPPMHP), layanan perbankan terutama Bank Sultra, jaringan komunikasi (hampir semua jaringan telepon selular bisa), dan sarana pembinaan nelayan (gedung serba guna di PPS Kendari). Pabrik es juga dibutuhkan pasca operasi penangkapan untuk penanganan ikan selama penjualan di TPI atau bila cold storage tidak bisa 
menampung ikan hasil tangkapan. Hal ini tentu sangat mendukung bagi pengembangan usaha perikanan tangkap unggulan.

Usaha perikanan tangkap unggulan terpilih umumnya dioperasikan dalam skala besar dan diyakini kebutuhan operasi penangkapan ikan maupun layanan pasca operasi pasti sangat banyak. Menurut Kusumawati \& Huang (2015) dan Samida et al (2018), pemenuhan kebutuhan operasi merupakan kunci utama keberhasilan operasi penangkapan ikan, sementara pelayanan dalam pendaratan, handling, dan pemasaran hasil perikanan akan mempengaruhi kontinuitas usaha. Sedangkan menurut Lubis et al (2012) dan Septia et al (2012), kinerja pelabuhan perikanan dan pendukungnya akan menjadi penentu tumbuhan dan berkembangnya usaha perikanan tangkap di suatu kawasan pelabunan perikanan. Oleh karena itu, peningkapan aktivitas penangkapan terutama dengan pengembangan usaha perikanan tangkap tertentu yang unggul, harus memperhatikan kesiapan fasilitas pendukung tersebut. Gambar 1 menunjukkan hasil analisis tingkat kesiapan/readiness level (RL) dari fasilitas pendukung yang ada di kawasan PPS Kendari.

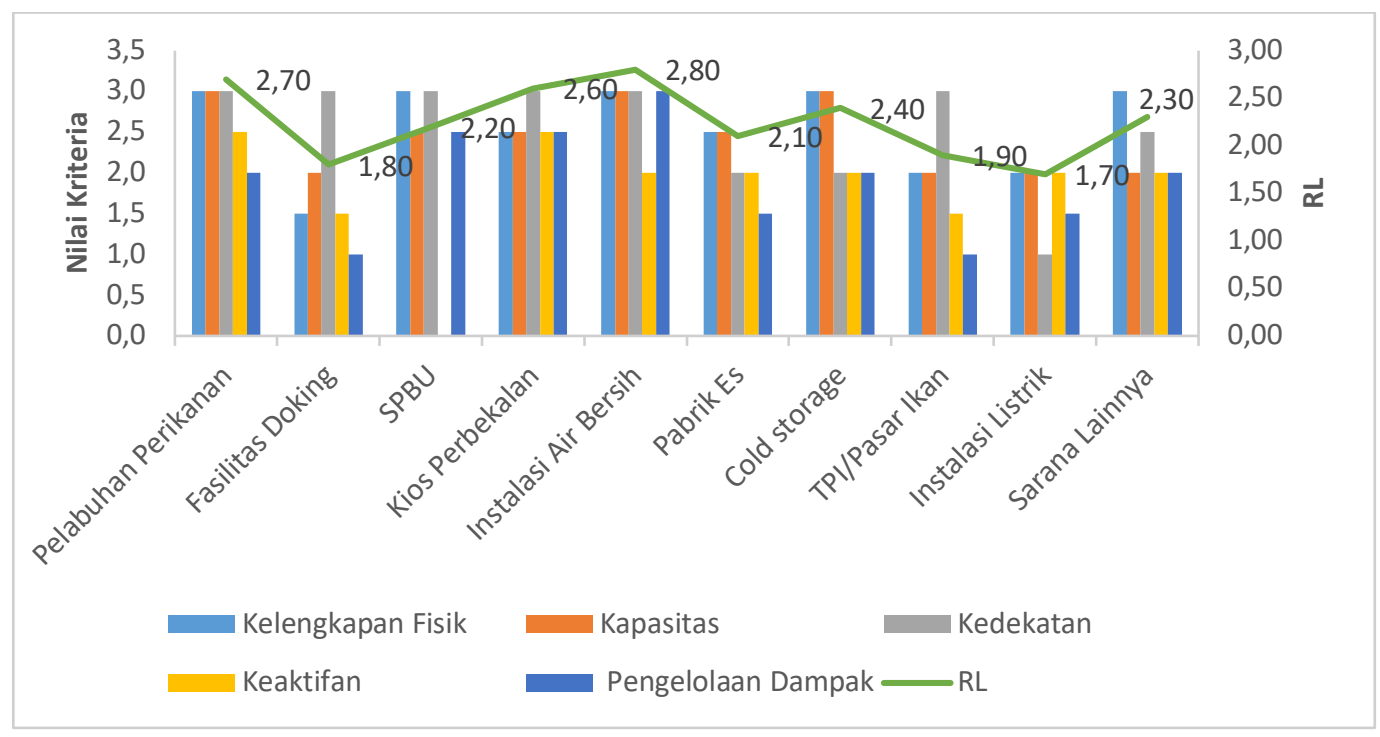

Gambar 1. Hasil analisis tingkat kesiapan (RL) fasilitas pendukung

Hasil analisis tingkat kesiapan/readiness level (Gambar 1) menunjukkan bahwa terdapat tujuh fasilitas pendukung dengan tingkat kesiapan tinggi (RL : $>2-3$ ), tiga fasilitas mempunyai kesiapan sedang (RL : >1-2) dan tidak ada fasilitas pendukung yang tidak siap. Fasilitas pendukung dengan kesiapan tinggi untuk mendukung pengembangan usaha perikanan tangkap unggulan adalah pelabuhan perikanaan $(R L=2,70)$, SPBU $(R L=2,20)$, kios perbekalan $(R L=2,60)$, instalasi air bersih $(R L=2,80)$, pabrik es $(R L=2,10)$, cold storage $(R L=2,40)$, dan sarana lainnya terutama LPPMHP dan perbankan $(R L=2,30)$. Tingginya kesiapan pelabuhan perikanan karena mempunyai kelengkapan fisik yang mumpuni, kapasitas yang besar karena berstatus pelabuhan perikanan tipe A, serta cukup dekat dengan lokasi pemukiman nelayan Kendari. Anggoro et al (2015) menyatakan bahwa kelengkapan fisik dan kapasitas terpasang merupakan dua hal untuk yang menentukan kinerja pelabuhan perikanan. Lubis et al (2012) menambahkan bahwa banyak pelabuhan perikanan yang tidak bisa difungsikan sebagaimana mestinya karena kapasitas terpasang tidak cocok dengan kapal/usaha perikanan tangkap yang beroperasi di lokasi.

Instalasi air bersih juga mempunyai kesiapan tinggi baik secara fisik, kapasitas, kedekatan, maupun pengelolaan dampak. Sumber air bersih untuk PPS Kendari berasal dari PDAM dan air tanah. Instalasi air bersih yang terpasang di PPS Kendari juga dilengkapi dengan unit pengolahan air dan instalasi Waste Water Treatment (WWT) untuk penanganan air limbah dari bilasan ikan dan peralatan yang digunakan. Cold storage juga tinggi kesiapannya karena jumlahnya lumayan banyak (24 unit) dengan kapasitas beragam mulai dari 150 ton, 100 ton, hingga 50 ton. Tingkat kesiapan TPI/pasar ikan, 
fasilitas docking, dan instalasi listrik tidak sebagus tujuh fasilitas pendukung lainnya. Untuk TPI/pasar ikan, cukup dekat dengan pelabuhan dan tempat tinggal nelayan, tetapi kurang lengkap sarana pendukungnya sehingga tidak bisa optimal dalam penggunaannya. PPS Kendari cukup jauh dari pusat Kota Kendari dan suplai listrik terkadang tidak lancar terutama bila di dalam kota kekurangan pasokan. PPS Kendari sudah menyiapkan genset untuk antisipasi, namun kapasitasnya terbatas. PPS Kendari (2017) menyatakan bahwa semua fasilitas pendukung yang pemanfaatannya berkaitan langsung dengan operasi perikanan seperti perbekalan, suplai BBM, energi, air tawar, dan aktivitas pasar harus terpenuhi dengan baik di kawasan perikanan. Sedangkan menurut Anggoro et al (2015) dan Mustaruddin et al (2015), kesiapan fasilitas terutama sumber energi dan air bersih menjadi pertimbangan investor dalam berinvestasi pada aktivitas collecting ikan, industri pengolahan, dan pemasaran perikanan di suatu kawasan pelabuhan perikanan.

\section{KESIMPULAN DAN SARAN}

\section{Kesimpulan}

Usaha perikanan tangkap yang unggul untuk dikembangkan di kawasan PPS Kendari adalah purse seine $(\mathrm{VA}=1,722)$, jaring insang hanyut $(\mathrm{VA}=1,713)$, payang $(\mathrm{VA}=1,607)$, dan pancing tonda $(\mathrm{VA}=1,302)$. Fasilitas pendukung dengan kesiapan tinggi di kawasan PPS Kendari adalah pelabuhan perikanaan $(R L=2,70)$, SPBU $(R L=2,20)$, kios perbekalan $(R L=2,60)$, instalasi air bersih $(R L=2,80)$, pabrik es $(\mathrm{RL} 2,10)$, cold storage $(\mathrm{RL}=2,40)$, dan sarana lainnya terutama LPPMHP dan perbankan ( $\mathrm{RL}$ $=2,30)$. Fasilitas pendukung dengan kesiapan sedang adalah fasilitas docking $(\mathrm{RL}=1,80)$, TPI/pasar ikan $(\mathrm{RL}=1,90)$, dan instalasi listrik $(\mathrm{RL}=1,80)$.

\section{Saran}

Kerjasama stakeholder terkait (Pengelola PPS Kendari, PEMDA, BKPM Daerah) perlu ditingkatkan untuk mendorong nelayan, masyarakat, dan investor mengembangkan usaha perikanan tangkap dari jenis unggulan. Investor besar juga perlu diberi kemudahan untuk berinvestasi pada fasilitas pendukung yang diperlukan.

\section{DAFTAR PUSTAKA}

Anggoro DS, Ismail, Pramonowibowo. 2015. Strategi pengembangan Pelabuhan Perikanan Samudera (PPS) Kendari, Kota Kendari, Sulawesi Tenggara. Journal of Fisheries Resources Utilization Management and Technology. 4(4): 67-77.

[Ditjen] Direktorat Jenderal Perikanan Tangkap. 2018. Pemetaan Wilayah Pengelolaan Perikanan Republik Indonesia. Jakarta (ID): Ditjen Perikanan Tangkap.

Fernández N, Fernández-Boán M, Verísimo P, Freire J. 2013. Assessing the spatial variability, level and source of organic chemical contaminants in bivalve fishing grounds on the Galician coast. Marine Pollution Bulletin. 71(1): 291-301.

[FAO] Food and Agriculture Organization. 1995. Code of Conduct For Responsible Fisheries (CCRF). Rome: FAO, pp. 46

Kuntoro M, Listiarini T. 1983. Analisa Keputusan, Pendekatan Sistem Dalam Manajemen Usaha dan Proyek. Bandung (ID): Baskara, 226 hal.

Hendri L, Tadjudah M, Mustafa A. 2019. Efektifitas hasil tangkapan pancing tonda dengan menggunakan umpan buatan yang berbeda di Perairan Pulau Binongko Kabupaten Wakatobi. Jurnal Manajemen Sumberdaya Perairan. 4(4): 298-305. 
Huang HW, Swimmer Y, Bigelow K, Gutierrez A, Foster DG. 2016. Influence of hook type on catch of commercial and bycatch species in an Atlantic tuna fishery. Journal of Marine Policy. 65(1): 68$75 p$.

[KKP] Kementerian Kelautan dan Perikanan. 2014. Rencana Strategis Kementerian Kelautan dan Perikanan Tahun 2014-2019. Jakarta (ID): KKP.

Kusumawati I, Huang HW. 2015. Key factors for successful management of marine protected areas: A comparison of stakeholders' perception of two MPAs in Weh island, Sabang, Aceh, Indonesia. Journal of Marine Policy, Vol 51 (1), pp. 465-475.

Lubis E, Pane AB, Muninggar R, Hamzah A. 2012. Besaran kerugian nelayan dalam pemasaran hasil tangkapan : Kasus Pelabuhan Perikanan Nusantara Palabuhanratu. Maspari Journal. 4 (2): 159167

Mustaruddin, Baskoro MS, Kandi O, Nasruddin. 2017. Environmental and technical approach in the selection of fishing gear featured in WPP 571 Aceh. IJSBAR. 31(3): 44-53.

Mustaruddin, Baskoro MS, Purwanto B. 2015. Pengembangan investasi usaha perikanan tangkap unggulan di Bau-bau, Sulawesi Tenggara. Prosiding Seminar Nasional Perikanan Tangkap VI, 22 Oktober 2015. Hal 193-207.

[PPS] Pelabuhan Perikanan Samudera Kendari. 2017. Profil Perikanan Pelabuhan Perikanan Samudera Kendari. Kendari (ID): PPS Kendari.

[PPS] Pelabuhan Perikanan Samudera Kendari. 2016. Statistik Perikanan Pelabuhan Perikanan Samudera Kendari Tahun 2015. Kendari (ID): PPS Kendari.

Prabowo, Wiyono ES, Haluan J, Iskandar BH. 2013. Kinerja pembiayaan perikanan skala kecil di Kota Tegal, Provinsi Jawa Tengah. Marine Fisheries. 4(1): 1-9.

Samida, Anadi L, Abdullah. 2018. Analisis pendapatan usaha purse seine di Pelabuhan Perikanan Samudera (PPS) Kendari dan faktor-faktor yang mempengaruhinya. Jurnal Manajemen Sumberdaya Perairan. 3(2): 125-134.

Septia R.T., A. Riris, A. Fitri. 2012. Analisis finansial unit penangkapan bottom gillnet di Pelabuhan Perikanan Nusantara Sungailiat, Bangka Belitung. Maspari Journal. 2(1): 70-73. 